\title{
To Have Both Roots and Wings: Nested Identities in the Case of Bulgarian Students in the UK
}

\author{
Bulgarian migrants and university students in particular, have recently fallen into \\ the spotlight of British media (Kirkup 2013), firmly positioned within fervent \\ immigration debates. Drawing on Brewer's (1999) concept of nested identities, \\ this paper explores how Bulgarian university students in the UK manage four \\ different identifications: national, European, migrant and student. Thus, the \\ process of establishing nested identities is investigated on three different \\ contextual levels: the transnational, regional and the everyday (at university and \\ at the workplace). Paying particular attention to the factors that influence the \\ process, this article also scrutinises its implications for Bulgarian students' values \\ and perceptions. Utilising semi- structured interviews and participant \\ observation with Bulgarian students, this paper will argue that the four \\ identifications emerge as highly dynamic, context- specific and constantly \\ negotiated relationships. Retrospectively, this article aims to contribute not only \\ to current literature on Bulgarian migration but also to wider debates on \\ transnational youth identities.
}

Keywords: nested identities, Bulgarian, student, migrant, European, values

\section{Introduction}

Sofia Airport, bearing the rather unfriendly name of "Vrazhdebna" (meaning "hostile" in Bulgarian) is not simply the main airport in Bulgaria but its' Terminal 1 and 2 have popularly been viewed as a symbolic reference point, epitomising Bulgarians' urge to migrate. Moreover, Sofia airport has emerged as a social space where questions of identity and belonging intertwine, delineating the contours of migrant narratives. Likewise, the airport is seen as a site where the dilemma whether to leave the country or not materialises - a dilemma quite prominent in students' narratives.

To understand the nature and characteristics of the implications of the context, it is necessary to scrutinise the wider processes of Europeanization, globalisation and 
technologization which have had a profound effect both on the nature of Bulgarian migration and on the people themselves.

In that sense, student migration, although traditional for Bulgaria migratory outflow, has been influenced by a number of phenomena that have altered its character. Firstly, the convenient travel options, affordable tuition fees, along with the removal of visas within the EU and various EU- funded exchange programmes have encouraged intra- European student mobility, and Bulgarians are no exception. Indeed, this trend was timely captured by Chavdarova's study with final year pupils prior to Bulgaria's EU accession with $60 \%$ of her respondents declaring that they would apply at a university abroad (2006, 58). Secondly, the booming "business with education" has emerged as a key factor due to numerous educational fairs being organised where foreign universities are showcased, featuring agencies ready to assist with the application process. Finally, the introduction of English language classes in the second graders' curriculum has strongly emphasised that the 'new realities in Europe and the world' necessitate communication in a 'multicultural environment' (Ministry of Education and Science, 2001, 1). In light of these developments, it is unsurprising that the popularity of British universities amongst Bulgarian students has steadily risen since the country joined the EU in 2007. Therefore, according to estimates of the State Agency for Bulgarians Abroad in 2012, there were 10000 Bulgarian students in UK universities (Stoyanova 2012). In comparison, only 30 young Bulgarians specialised in England between 1878 and 1912 (Tanchev, 2004, 147). Therefore, it becomes obvious that while pursuing education in the UK is not a new phenomenon per se, Bulgaria's EU accession marks a new migratory period.

Additionally, the country's transition to democracy has led to dramatic socioeconomic changes that have arguably had a tremendous effect on the values and 
perceptions of young people in the country. Popularly referred to as the "children of the transition", they are unfamiliar with censorship, closed borders and totalitarian propaganda (Nikolov 2013). In that sense, Chavdarova categorises this generation as 'new Bulgarians', or 'carriers of new values' (2006, 57), among which the most prominent are individualism, pragmatism, cosmopolitan openness and refusal to adhere to traditionalism $(2006,60)$. Moreover, the study clearly underlines that these values contribute to a readiness for mobility among young people in Bulgaria (Chavdarova, 2006, 66). Therefore, Bulgarian students in Britain find themselves situated in a rather interesting and complex transnational context that challenges and transforms their identities and impacts upon their values and perceptions.

If Sofia "Vrazhdebna" suggests hostility, hardly any British airport bears the name "Welcoming". On the contrary, Bulgarian migratory flows have recently been in the midst of avid immigration debates in Britain. With the removal of labour restrictions for Bulgarians on January $1^{\text {st }} 2014$, the British press has forged negative rhetoric, (Culliford 2013; The Telegraph 2013; Mahmood 2013) unleashing processes of othering. This consistent construction of the "Bulgarian-as-the-Other" closely resonates with and is shaped by three larger tendencies evident in Britain: stricter immigration policy and border control (May 2010; Cameron 2014), a shift away from multiculturalism (Però 2008) and strong eurosceptism (Farage 2012). These wider tendencies have had a profound effect on the experiences of Bulgarian students in Britain. As Bulgarian nationals they were also subjected to labour restrictions between 2007 and 2014 which limited their working hours during term time, premised on being issued a student registration certificate (UKBA 2011). The prolonged procedure that also lacked transparency rendered many students vulnerable because certificates served as a prerequisite for finding part-time work or for undertaking placements as part of 
their studies (Dimitrova 2012). Additionally, Bulgarian students and their Romanian peers came to the spotlight of public discourse in November 2013 when the British government announced that they would suspend the provision of student loans covering living expenses, due to a 'suspicious' increase in the applications from nationals of both countries (Kirkup 2013). Evidentially, both of these instances demonstrate the rather hostile context that Bulgarian students find themselves in.

Therefore, this paper has two overarching goals. Firstly, it aims to contribute to the growing literature on Bulgarian student migration in the UK (Ivancheva 2007; Maeva 2010; Chongarova 2010a, 201b, 2011). This will be approached by using nested identities (Brewer 1999; Medrano and Gutiérrez 2001) as a critical lens to explore how individuals combine different group identity characteristics. More specifically, I will look at three different elements of the process - the relationships among different identities, the situational context where the dynamic changes and the implications for values and experiences of Bulgarian students in the UK. The latter will help to elaborate Chavdarova's (2006) profile of the 'new Bulgarians'. Secondly, the article aims to complement and enrich the wider debates on transnational migrant youth identities by arguing for the inclusion of the experiences of EU students in that theoretical domain. Furthermore, it will be claimed that nested identities serves as a particularly suitable analytical prism for the understanding of transnational youth's identity construction processes.

To aid this exploration, the next section presents a theoretical backbone to the discussion which will be followed by the study's research framework. It will then go on to discuss two significant empirical sections. The first one focuses on an analysis of the construction of Bulgarian students' nested identities, scrutinising specifically the situational context where the dynamic changes. From that perspective, the analysis of 
the overarching social context as well as the literature on intra- European student migration and Bulgarian youth (King 2002; King and Ruiz- Gelices 2003; Mitev and Kovacheva 2014) have brought forward four main identifications of being a Bulgarian, a European citizen, a student and a migrant. While the specificity of each will be outlined, the main focus of analysis will be on their overlapping and/ or contradictory points. The second empirical section focuses on the implications of the process of establishing nested identities upon experiences and values of the participants. Finally, the conclusion summarises the findings, endorsing nested identities as a concept that can more accurately capture the identity construction processes of young migrants, situated in a transnational context.

\section{Transnationalised Youth Identities}

Before delving into the operationalization of nested identities, this section will look more closely at students' experiences, and argue that their nature has become imminently transnationalised. The latter highlights identities' multiplicity and fluiditycharacteristics which come to the fore in host society contexts. This discussion will go on to look more closely at the specific example of Bulgarian students in Britain and the four identities of being a Bulgarian, a European citizen, a student and a migrant that emerge as central, arguing that nested identities offers a useful framework for their analysis.

The forces of globalisation have changed not only the outlook of societies but also the life courses of many people who have had to navigate through shifting social terrains to constantly 'reinvent' themselves (Elliot 2013). In such a setting, flexibility is a highly praised human quality. Therefore, '...spatial mobility, and by extension, 
transnationality, are important preconditions for successful navigation of social life, whereas immobility connotes stasis, decline and disadvantage' (Faist, 2013, 3-4). Nevertheless, is it possible to classify international students as transmigrants? Glick Schiller, Basch and Szanton Blanc argue that 'transnational migration is the process by which immigrants forge and sustain simultaneous multi- stranded social relations that link together their societies of origin and settlement' $(1995,48)$. Consequently, while Portes reminds us that 'not all immigrants are transnationals', he also emphasises that higher human capital and by extension-education, increase the likelihood of engagement in transnational activities (2003, 876 and 886). Thus, I argue that the intensification of intra- European student migration and the rise of 'reinvention' (Elliott 2013) offer the necessary conditions for a transnationalisation of students' experiences. While not all student experiences fall in this category, full- time university students who are studying in different EU member states represent an interesting migration chronotope whereby ideas of transnationalism emerge, unlocking a series of processes that influence identity construction and stretch the sense of belonging. Therefore, applying a transnational approach to the research on student migration between EU member states is necessary as it allows the exploration of '...the relationship between the] transformation among spaces, places, and identities to reconsider the [student] experience' (Haller and Landolt, 2005, 1183). Indeed, the transnational approach in migration research centres upon the dynamics of a process, underscoring a multiplicity (Bauböck, 2010) and fluidity (Haller and Landolt 2005; Robins and Aksoy 2010) of attachments and belongingness. Moreover, this approach offers an understanding of the ways in which students navigate their various identities in social contexts that are fastpaced and constantly changing. 
Therefore, Bulgarian students in Britain are an interesting case- study. Their social context, discussed briefly in the previous section as well as literature reviewed on the topic of intra- European student migration (King 2002; King and Ruiz- Gelices 2003) and Bulgarian youth (Mitev and Kovacheva 2014), hint that four main identities emerge as prominent: national, European, student and migrant identity. Each of the four identities appears as rather complex, and in some cases - ambiguous which further complicates the process of their management. On the one hand, migrant and student identities seem to be trapped into the sociological debate on whether students should be considered as migrants (King 2002; King and Ruiz- Gelices 2003). Even though some classify them as a subset group of highly skilled or elite migration (Chongarova 2010a, 2010b, 2011); others still argue over different terminologies such as mobility and migration and their connotations (for various definitions see Urry 2000; Favell 2008a, 2008b; Castles and Miller 2009). On the other hand, national and European identities find themselves in the midst of the nationalism- cosmopolitanism battlefield. Consequently, national identity is perceived as '...subject to ongoing negotiations involving competing visions of social order, alternative interpretations of history and delineations of national self' (Karner, 2011, 21). The same view of the multidimensionality and fluidity of the concept is shared by Guibernau (2007). Simultaneously, European identity, is categorised as 'embryonic' and 'non- emotional' (Guibernau, 2007, 115-116). Ultimately, this points to European identity's lack of potential to reach the same degree of sentiments provoked by its national counterpartan argument shared by Smith (1995). While this debate suggests a rather conflictual relationship between the two identities, Cram claims that this connection could be ' $[. .$. synergestic, producing an outcome which is greater than the sum of its parts' (2009, 101). Indeed, in an interconnected world where social and spatial mobility often 
intertwine, the firm boundaries of attachments become blurred and ongoing processes of identity construction overlap. This is particularly the case for young Bulgarian university students in Britain who, navigating through both home and host society contexts, have had to not only adapt to this reality but also to reinvent themselvesprocesses that imminently affect their identities and attachments.

Therefore, studying identities produced by "new" realities requires moving away from binary divisions and exploring different theoretical frameworks that can better accommodate their dynamic, context- specific nature. In that sense, nested identities is a useful concept that captures both the context and the interconnectedness of each individual's multiple identities. Moreover, it cuts across the boundaries of each identity, focusing on the dynamics of the process of identity construction itself.

Reaching out to social psychology, the roots of the idea point to Lawler's definition of nested groups as 'composite, generalized others constituting distinct referential comparisons and identities for individuals (1992, 327). Lawler's theoretical framework suggests social structures as the main determinants of attachment to nested groups, paying little attention to individuals' agency. The concept is further developed in Brewer's optimal distinctiveness theory, which 'focuses on resolving opposing needs for differentiation and inclusion by adopting a single social identity that meets both needs' $(1999,188)$. Consequently, this theory is concerned with how individuals can experience the relationship between two different social identities. Therefore, nested identities essentially denotes '...one identity...[that] is superordinate and the other is a differentiated subpart or subgroup identity ' (Brewer, 1999, 190). Brewer further clarifies that while '...the two identities may function in a complementary manner to serve different needs', the precedence of one over the other in a given situation depends on '...which social motive (inclusion or differentiation) has been activated' (1999, p. 
190). Thus, the emphasis is on the compatibility of identities, whilst also taking into consideration the principle that triggers identity construction. Additionally, Medrano and Gutiérrez (2001) have utilised the concept to analyse the degree of identification with Europe and the relationship between national and European identity in Spain. Accordingly, nested identities emerge as an instrumental concept that allows the scrutiny of the relationships between identities as they occur in their specific context.

Nonetheless, the objective of this paper is more ambitious. Students in a transnational context need to "manage" a multitude of identities, the analysis of which in turn requires stretching the nested identities concept to capture fully the experience of these people. Thus, in the particular case of Bulgarian students in Britain the nested identities concept is utilised to evaluate the relationship and dynamics of Bulgarian, European, migrant and student identities in their transnational context as well as their implications for the values and perceptions of young Bulgarians.

Before analysing that more in-depth, it is important to provide more information about the "mechanics" of the study itself.

\section{The study}

Studying young people's processes of identity construction, values and perceptions in a transnational environment requires a lot of sensitivity to a number of elements such as specificities of context, alertness to dynamics and the role and effect of social structures and everyday practices. The response to these challenges is clearly reflected in the research design and techniques that this study has utilised to address the question of what it means to be a Bulgarian, a student, a European citizen and a migrant in an increasingly hostile context. Therefore, the research for this paper was carried out in two stages. The first one involves thirteen semi- structured interviews conducted in the 
summer of 2011 in the midst of growing dissatisfactions among students regarding the procedure for applying for registration certificates. The second set was generated through multi-sited ethnographic fieldwork between August 2013 and April 2014 that involved participant observation as well as 20 semi- structured interviews. This second phase captures the impact of the intensification of negative rhetoric in the British press towards Bulgarian migrants and students in particular before and after the removal of labour restrictions on January $1^{\text {st }} 2014$.

With regards to the first data set, my thirteen participants were aged between 19 and 25, where five were male and eight- female students of which seven were undergraduate students, four- taught postgraduates and two- borderline cases. They were enrolled in universities in London, Wales, Scotland and Southwest England. I used a snow- balling technique to recruit participants. The larger number of undergraduate students could be explained by the fact that Bulgaria joined the EU in January 2007; therefore, after this point Bulgarian nationals' tuition fees dropped to home students' level, which ultimately makes Bulgarians born in 1988 the first big wave applying to UK universities. The two borderline cases signify people who have completed their undergraduate degree, worked for a year in the UK and were at that point considering applying for postgraduate courses. Therefore, it was expected that their opinions would differ significantly from those of the rest of the group.

The second data set involved students aged between 19 and 29, of which nine were female and eleven - male. The majority (fifteen) of the respondents were undergraduates, one was a postgraduate taught student and four were $\mathrm{PhD}$ students. They were enrolled in universities in Scotland, the Midlands and Northern England. Participant observation was particularly helpful in highlighting specific situations where the dynamic between various identities changes. A snow- balling technique with 
purposive sampling ${ }^{1}$ was utilised to ensure a wide range of participants according to the following criteria: age, location in Britain, gender and educational level. Thus, my sample complemented the previously generated data set. In both cases, the data was analysed thematically. To preserve the anonymity of my respondents, I have used pseudonyms within this paper. Also, it is important to mention that this paper does not make any claims for generalisations; rather, it should be regarded as a snapshot of a range of Bulgarian student migratory experiences.

\section{Young Bulgarians' Nested Identities}

My fieldwork with Bulgarian university students in the UK has uncovered a complex amalgamation of identities that are extremely dynamic, fluid and context- specific. The transnational student experiences of Bulgarians in Britain reveal what Stuart Hall has termed as a process of 'becoming' rather than 'being' whereby identities are '[...] not the so- called return to roots but a coming- to-terms- with 'routes" $(1996,4)$. Taking context and dynamics into consideration, this section will provide an analysis of young Bulgarians' nested identities on three different levels: transnational (host and home society), regional level as well as the everyday — in particular university and workplace settings. In each case, the nexus among national, European, student and migrant identity will be scrutinised, paying particular attention to factors that trigger changes in their relationship. Ultimately, this section will argue that the 'process of becoming' not only redefines the meaning of each type of attachment but it also urges Bulgarians to negotiate the boundaries of nested identities in various situations.

Mapping out Bulgarian students' identities against their transnational context, reveals that being a Bulgarian and a student emerge as the higher order identities in 
comparison to being a European and a migrant. Nonetheless, the data indicates that a number of factors have produced three different variations of this relationship. Firstly, Bulgarian students' transnational experiences have triggered a strong sense of patriotism which has resulted in the precedence of national identity over the others. Balkan - a first year business student - explains that '...it is important to carry your origins (roots) within you no matter where you go'. This suggests that the affiliation with a certain nationality gains particular importance not in spite of but exactly because of crossing borders. The majority of respondents interviewed throughout both phases of the study confirmed the consistency of this finding. On the one hand, this is rather unsurprising, considering that all participants were either members of or closely associated with Bulgarian student societies within their respective universities, including the borderline cases- Ivan and Kalina. The student societies present opportunities for young Bulgarians to celebrate national holidays and to socialise with other Bulgarians. This cultural aspect, combined with the strong connection that all respondents maintain with their families in Bulgaria through frequent home visits and Skype calls, emerge as influential factors that foster strong national identity.

Moreover, my fieldwork discovered that this strong sense of national identification is associated with and nurtured by different forms of banal nationalism (Billig 1995) such as buying Bulgarian products, cooking national food and following Bulgarians news. However, it is quite notable that certain critical moments in the home country were able to trigger or strengthen both student and national identities, demonstrating a strong transnational political engagement. Therefore, in response to the 2013 anti-government protests against the appointment of a shadowy media mogul as head of Bulgarian national security, students at the Sofia University decided to occupy the university. Interestingly, some of my participants such as Scotland- based Hristian 
and Marko directly participated in the protests whilst being home for the summer, whereas others such as 20- year- old Adrian and Ignat organised various activities ranging from videos to photos and declarations in support of their colleagues in Sofia. Their active transnational political engagement, brought to the fore the strong precedence of their student and Bulgarian identities, proving that certain dramatic moments and events across borders can strongly influence the process of identity construction.

Another aspect that points to the precedence of national identity over other identities is influenced by the recent negative rhetoric in the British press in relation to Bulgarian migrants. Interestingly, for some participants this has resulted in stronger identification with Bulgaria. Kamelia, a third year Sociology student in Scotland, clearly demonstrates this point. For her, the overarching negative environment has provided the stimulus to identify very strongly as a Bulgarian- a process subtly achieved through her active engagement with various student initiatives where she takes the opportunity to present a more positive side of her country. Indeed, by stating that 'I try to always be my best version', she admits that this is almost a 'mission' of hers. Thus, using this technique to counter the overarching negativity in the host society ultimately results in strengthening participants' sense of national belonging.

While the hostile environment that Bulgarian students find themselves in has made some feel more Bulgarian, for others like Kalina, the same factor has resulted in a more nuanced interpretation of national identity, supplemented by stronger student attachment. Despite Kalina's strong sense of national belonging, she quickly clarifies: 'I didn't come here to pick strawberries and be a farmer...I came here to study'. Therefore, while her national identity satisfies the urge for inclusion, the subordinate student one serves as a way to disassociate herself from other Bulgarians. 
Additionally, European citizenship serves as a reason for intensifying similarities and differences in a host society context. Based on the highly eurosceptic British context, young Bulgarian students categorise European citizenship as a constantly negotiated relationship sometimes leading to nested identities that create differences in treatment. Margarita mentions double standards when she talks about it: 'I think we are now a kind of hybrid EU citizens - we are on paper EU citizens but we're kept out of full citizenship as much as this is possible'. "Hybrid" here signifies that European citizenship operates as a dividing line within European identity, something that Levy and Sznaider (2007) point to when they discuss second- class European citizenship. External categorisation appears much stronger and European identity is not able to bridge differences and establish belonging. Thus, the data prove that when embedded within the wider British host society context European citizenship can operate as a catalyst of differences. Hence, analysing Bulgarian students' nested identities as contextualised in their wider transnational milieu reveals that the very nature and the relationship among the various identities are rather fluid and constantly negotiated.

The same phenomenon can be observed when students' identities are analysed in their regional context. Indeed, the data confirms the precedence of national identity over European identity (Smith 1995), though the latter is slightly less "embryonic" than Guibernau (2007) claims. This is particularly the case in Scotland. Although Bulgarian students as European citizens pay the same tuition fees as home students in the UK, in Scotland equally to locals their tuition fees are covered by the Student Awards Agency for Scotland. Thus, the more positive environment there makes Politics student Marko and Sociology student Yana conclude that the Scottish are more 'warm- hearted than the English' and much 'friendlier'. The same view is shared by first year PhD student 
Stamen when he claims that in Scotland 'they don't look at you with daggers in their eyes because you are a foreigner [...] you feel more European'. Interestingly European identity is associated with a sense of belonging - something that students in London such as Rada report as well. 25- year old postgraduate student Veronika, also based in London explains further that she does not 'regard EU citizenship merely as a number of legal rights but it also involves a sense of belonging to common European values and 'space'. Thus in specific regional contexts in the UK, the friendlier, more multicultural environment transforms European citizenship into a facilitator that strengthens the sense of European belonging which synergistically interacts with national and student identities.

Finally, specific social situations alter the dynamics of nested identities bringing migrant identity to the fore. Indeed, regarded in the wider transnational and regional contexts, being a migrant does not appear as salient. Instead, the majority of respondents regard themselves as mobile young people who study abroad to ensure a successful career path in a highly competitive and globalised world. Thus, the urge for reinvention described by Elliott (2013) has normalised the act of crossing borders to ensure social mobility as Faist (2013) has rightly argued. However, in particular social situations migrant identity resurfaces, albeit as an external categorisation imposed on students. Hence, the data reveals a sharp change in the dynamic between student and migrant identities when placed in the everyday context of the university or the working environment. This is certainly the case not only for Kalina and Ivan as people who have found themselves outside of academia but also for young Bulgarians who both study and work such as Teodor. He affirms: 'When you are looking for a low- skilled job because you are a foreign student with some level of English which is questionable from a country that most people haven't heard of...you feel the difference in treatment'. 
While the university provides a safer environment which eases the feeling of difference and lack of belonging usually associated with migratory experiences, the work environment sharply changes that dynamic. Margarita- a girl about to embark upon a postgraduate course in Scotland- shares the same frustrations while working part- time as a waitress. She confesses that 'at uni [she] always felt like...[she] was treated equally', whereas at work '...the manager would regularly repeat one and the same thing 2-3 times and talk very slowly. Also, I'd get to do more refilling of fridges and worked more in the kitchen compared to the other waitresses'. Correspondingly, the different situational contexts swayed the process of identification in either direction- either strengthening student identity or highlighting the feeling of being a migrant. An interesting finding is that the priority of each identity over the other is usually associated with different external categorisations. Thus, student identity as a higher order identity is associated with feelings of inclusiveness, belonging, equality and safety guaranteed by the multicultural university environment, whereas exactly the opposite is the case in work environments.

Thus, the analysis of nested identities as occurring in their specific contexts on three different levels - the wider transnational one, the regional one as well as the everyday clearly demonstrates that the process of identification is rather dynamic. This strengthens the fluidity of meaning attached to specific identities, simultaneously necessitating the negotiation of their relationship in various contexts. While the specificities of this turbulent process were at the core of this section, the next part will focus on its implications for the respondents' values and perceptions. 


\section{Values and Perceptions}

Twenty-two year old Marko who is passionate about travelling and debating told me a story that his family often jokes about. When he asked his parents why they did not name him after his grandfather as the Bulgarian tradition postulates, they said that they had chosen a name that can be easily pronounced abroad. This anecdote clearly indicates that mobility and by extension, the need for reinvention in a fast- paced world have become not only normalised but also nurtured. Thus, the choice to study abroad not only affects young people's identities but it also marks a profound shift in their values and perceptions. Therefore, this final empirical section will critically discuss some of the most prominent characteristics of those "new Bulgarians" and the implications for their values and experiences.

Unsurprisingly, pragmatism emerged as a strong quality as many of them have been planning and preparing for study abroad. Balkan summarised this in the following way: I did a research on the UK. I was sure that obtaining a degree in a UK university will give me many prospects in the future'. The majority of the respondents followed that reasoning with the exception of Plamen who made his decision to do a master's degree in the UK at the last possible moment. Most of the participants, however, followed a carefully planned pattern, as their university application was preceded by enrolling at a high school where English was extensively taught, revealing them as pragmatic, rational actors.

The second quality that became evident in my conversations with participants was individualism. For Kiril, Teodor, Kalina, Ivan, Iskra and Rada that meant pursuing their dreams and career goals even though they did not have many friends abroad or did not have prior information about study in the UK - it meant making their own way. Students' mobility choices and transnational experiences have also led to strengthening 
their family values and connections as family support was perceived as crucial throughout the entire migratory project from applying to a university through studies and graduation. Far from being idealistically naive though, their image of Bulgaria remains two- fold. On one hand, it is the state and the economy that cannot adequately meet their needs (and skills) at this moment but on the other, it remains their motherland - the place safeguarding their memories, where their friends and family await their return one day.

Finally, the synthesis of Bulgarian and European identity on an individual level, proves rather influential and transformative and leads to the adoption of cosmopolitan values. Equality, appreciation of cultural diversity, independence and personal realisation are among the most outstanding ones. Interestingly, the lower order EU identity and European citizenship trigger most of these values. Open- mindedness, travel and exploring new cultures are also among the priorities: a by- product of establishing Bulgarian and European nested identities.

To summarise, the myriad of responses and the variety of reasoning behind each demonstrate that Bulgarian students in Britain do not represent a homogenous group and as such their nested identities are strongly individual and context- dependent.

\section{Conclusion: Roots and Wings}

'I want to live in this kind of cosmopolitan Europe, one in which people have roots and

$$
\text { wings' (Beck, 2007, p. 49) }
$$

This paper set out to unravel the nature, context and implications of individuals combining different collective identifications. Focusing on the specific case of Bulgarian students in the UK, it was argued that the need for reinvention (Elliott 2013) in a globalised world has not only normalised intra- European student mobility but, as 
Faist (2013) has rightly claimed, it has also made it a prerequisite for successful social mobility. This ultimately highlights the necessity of applying a transnational perspective to the experiences of full- time EU students. Moreover, such a dynamic environment not only challenges the meanings attached to various identities such as national, European, migrant and student but it also imminently redefines their nexus.

To understand this phenomenon, the paper analysed the interplay of these identities in three contexts - in the wider transnational setting, in the regional milieu, and in everyday social situations - paying particular attention to the factors that underpin the various outcomes. In that sense, it is interesting that national and student identities emerge as superordinate while migrant and European identities are to a huge degree dependent upon them. Although migrant identity on a transnational and regional level is largely undermined either by European or student identity, it strongly reappears in the workplace. Interestingly, European and student identities are usually associated with feelings of inclusion and belonging while migrant identity suggests exclusion and hostility. With regards to Bulgarian and European identities, European citizenship appears as a facilitator, strengthening their symbiotic relationship in regional contexts. However, strong euroscepticism reverses the role of European citizenship from a facilitator of inclusion to a catalyst of exclusion in the wider host society. Thus, it becomes obvious that Bulgarian students' nested identities are highly fluid, contextspecific and dynamic.

Moreover, the article also scrutinised the implications that the process of negotiating identities in various contexts has upon the respondents' values and perceptions. In that sense, individualism and pragmatism are quite strong qualities that come to the fore when respondents share their plans, dreams and goals in life. While the first value (individualism) has infused their plans for pursuing a specific degree and 
career opportunities, the second (pragmatism) appeared to be strong when choosing a destination country. An interesting finding is that being mobile for Bulgarian students has not only become a necessity but also a value, giving them a chance to prove their skills and abilities. Ambitious, hardworking and rational, young Bulgarians studying in Britain have a chance to learn how to interact with people from different nationalities and backgrounds - a quality seen as an advantage in a fast- paced multicultural world. As they are expanding their horizons, however, not only do their patriotism and family values not diminish but they actually become stronger. Infused with cosmopolitan ideals, the "new Bulgarians" have demonstrated that they have both roots and wings: dreaming big and following their goals in life but never forgetting the place they have come from and the people they have left behind. As long as they remember their roots, they will always have a reason to go back and wings will take them there '...when Bulgaria is ready for us' as Kalina claims.

As a result, nested "identities" has emerged as a concept that is particularly instrumental in analysing multiple identities on an individual level by simultaneously taking into account the specificities of different contexts. Furthermore, stretching the concept proves beneficial beyond the specific case of Bulgarian students in the UK-it offers an analytical opportunity that enriches the scholarly debate on transnational youth identities.

\section{Acknowledgements}

I am incredibly indebted to the editors of this special edition, Professor Tracey Reynolds and Dr Elisabetta Zontini, for their helpful suggestions to earlier drafts of this paper. I would like thank three anonymous reviewers, an Identities Associate Editor, Emma Craddock and Rupal Patel for their constructive criticism. The responsibility for this paper, however, is mine alone. 
References:

Bauböck, R., 2010. “Cold Constellations and Hot Identities: Political Theory Questions about Transnationalism and Diaspora." In: R. Bauböck and T. Faist, eds. Diaspora and Transnationalism: Concepts, Theories and Methods. Amsterdam: Amsterdam University Press, 295- 320.

Beck, U., 2007. “Reinventing Europe- A Cosmopolitan Vision.” In: C. Rumford, ed. Cosmopolitanism and Europe. Liverpool: Liverpool University Press, 39- 51.

Billig, M., 1995. Banal Nationalism. London: Sage Publications.

Brewer, M., 1999. "Multiple Identities and Identity Transition: Implications for Hong Kong”. International Journal of Intercultural Relations 23 (2): 187- 197.

Cameron, D., 2014. "David Cameron's EU Speech: Full Text”. $B B C$ [online]. Available at: http://www.bbc.co.uk/news/uk-politics-30250299 [Accessed: November 29, 2014].

Castles, S. and Miller, M., 2009. The Age of Migration: International Population Movements in the Modern World. (4 $4^{\text {th }}$ ed.). Houndmills: Palgrave Macmillan.

Chavdarova, T., 2006. "Young People- Those New Bulgarians: What Do They Think About Bulgaria?" South- East Europe Review for Labour and Social Affairs 3/2006: 5767.

Chongarova, I., 2010a. Bulgarskite student v London: Obrazovatelni strategii $i$ migratsionni modeli. Available at: http://files.slovo.uni-plovdiv.bg/clic/bulgarianstudents-PRINT.pdf [ Accessed: June 7, 2014].

Chongarova, I., 2010b. "Studentski dilemi: Dozhivoten li e izborut "London”?", $B G$ Ben, Dekemvri 18, str. 6.

Chongarova, I., 2011. "Misia London”. V-k Plovdivski Universitet, 25 mart, str. 10.

Cram, L., 2009. “Introduction: Banal Europeanism: European Union Identity and National Identity in Synergy”. Nations and Nationalism, 15 (1): 101- 108. 
Culliford, G., 2013. "Next Stop UK: Romanians \& Bulgarians are Queuing Up for Handout Britain." The Sun, [online] . Available at:

http://www.thesun.co.uk/sol/homepage/news/4776276/Romanians-Bulgarians-arequeueing-up-for-handout-Britain.html [Accessed: February 5, 2013].

Dimitrova, A., 2012. “Za bulgarskite student Velikobritania dnes e “1984”.” Webcafe, [online]. Available at:

http://www.webcafe.bg/id_657125980_Za_balgarskite_studenti_Velikobritaniya_dnes e_1984. [Accessed: June 8, 2014].

Elliot, A., 2013. Reinvention. London: Routledge.

Faist, T., 2013. “The Mobility Turn: A New Paradigm for the Social Sciences?” Ethnic and Racial Studies, doi: 10.1080/01419870.2013.812229.

Farage, N., 2012. "New Year Message 2013.” [video online]. Available at: http://www.youtube.com/watch?v=TW64w9nLrqA [Accessed January 5, 2013].

Favell, A., 2008a. Eurostars and Eurocities: Free Movement and Mobility in an Integrating Europe. Oxford: Blackwell Publishing.

Favell, A., 2008b. "The New Face of East- West Migration in Europe.” Journal of Ethic and Migration Studies 34 (5): 701- 716.

Glick Schiller, N., Basch, L. and Szanton Blanc, C., 1995. “ From Immigrant to Transmigrant: Theorizing Transnational Migration.” Anthropological Quarterly 68 (1): 48- 63.

Guibernau, M., 2007., The Identity of Nations. Cambridge: Polity Press.

Haller, W. and Landolt, P., 2007. "The Transnational Dimensions of Identity Formation: Adult Children of Immigrants in Miami." Ethnic and Racial Studies 28 (6): 1182- 1214. 
Hall, S., 1996. "Introduction: Who needs identity?” In: S. Hall and P. du Gay, eds. Questions of Cultural Identity. London: Sage, 1-17.

Ivancheva, M., 2007. "Strawberry Fields Forever? Bulgarian and Romanian Student Workers in the UK", Focaal- European Journal of Anthropology 49: 110- 117. Doi: 10.3167/foc.2007.490109.

Karner, C., 2011. Negotiating National Identities: Between Globalization, the Past and 'the Other'. Farnham: Ashgate.

King, R. 2002., “Towards a New Map of European Migration.” International Journal of Population Geography 9: 89- 106.

King, R. and Ruiz- Gelices, E., 2003. "International Student Migration and the European 'Year Abroad': Effects on European Identity and Subsequent Migration Behaviour." International Journal of Population Geography 9: 229- 252.

Kirkup, J. 2013., "Student Loans to Bulgarians and Romanians Suspended." The Telegraph, [online]. Available at:

http://www.telegraph.co.uk/news/uknews/immigration/10461099/Student-loans-toBulgarians-and-Romanians-frozen.html [Accessed: June 12, 2014].

Lawler, E. J., 1992. "Affective Attachments to Nested Groups: A Choice- Process Theory." American Sociological Review 57 (3): 327- 339.

Levy, D. and Sznaider, N., 2007. "Memories of Europe: Cosmopolitanism and Its Others." In: C. Rumford, ed. Cosmopolitanism and Europe. Liverpool: Liverpool University Press, 158- 177.

Maeva, M., 2010. "Organizations and Institutions of Bulgarian Emigration in the UK." In: M. Karamihova, ed. European Dimensions of Culture and History on the Balkans. Sofia: Paradigma, 276- 291.

Mahmood, M., 2013. "Bonus Bulgar Benefits Rackets Exposed." The Sun, [online]. Available at: http://www.thesun.co.uk/sol/homepage/news/4845502/Bonus-Bulgarianbenefits-rackets-exposed-by-The-Sun.html [Accessed: 17 March, 2013]. 
May, T., 2010. The Home Secretary's Immigration Speech. UK Home Office.

Available at: http://www.homeoffice.gov.uk/media-centre/speeches/immigration-speech [Accessed: April 1, 2011].

Medrano, J. D. and Gutiérrez, P., 2001. "Nested Identities: National and European Identity in Spain.” Ethnic and Racial Studies, 24 (5): 753- 778.

Ministry of Education and Science., 2001. Uchebna programa po Anglijski ezik za II klas (parvi chuzhd ezik). Available at:

http://www.mon.bg/?go=page\&pageId=1\&subpageId=28 . [Accessed: June 17, 2014].

Mitev, P.-E. and Kovacheva, S., 2014. Mladite Hora v Evropeiska Bulgaria:

Sotsiologicheski Portret 2014. Sofia: Friedrich Ebert Stiftung.

Nikolov, D., 2013. “\#neochakvanite.” Webcafe, [online]. Available at: http://www.webcafe.bg/id_1245035277_ [Accesssed: April 30, 2014].

Però, D., 2008. "Political Engagement of Latin Americans in the UK: Issues, Strategies, and the Public Debate." Focaal- European Journal of Anthropology 51: 73-90.

Portes, A., 2003. "Conclusion: Theoretical Convergencies and Empirical Evidence in the Study of Immigrant Transnationalism.” International Migration Review 37 (3): 874892.

Robins, K. and Aksoy, A., 2010. "From Spaces of Identity to Mental Spaces: Lessons from Turkish- Cypriot Cultural Experience in Britain.” Journal of Ethnic and Migration Studies, 27 (4): 685- 711.

Rolfe, H., Fic, T., Lalani, M., Roman, M., Prohaska, M. and Dudeva, L., 2013. Potential Impacts on the UK of Future Migration from Bulgaria and Romania. National Institute of Economic and Social Research. Available at: http://www.niesr.ac.uk/publications/potential-impacts-uk-future-migration-bulgariaand-romania\#.UXMYUbU3v2o [Accessed: April 6, 2013]. 
Smith, A. D., 1995. Nations and Nationalism in a Global Era. Cambridge: Polity Press.

Stoyanova, V., 2012. "Bulgarskite studenti v chuzhbina sa pone 24 000.” Sega, [online]. Available at: http://www.segabg.com/article.php?id=622511. [Accessed: June $6,2014]$.

Tanchev, I., 2004. “Anglo- Bulgarian Relations in the Sphere of Education (19781912).” Bulgarian Historical Review 1-2: 139- 148.

The Telegraph, 2013. "Bulgarian Midwife Almost Injected New- Born Baby with Lethal Air Bubble." The Telegraph, [online]. Available at: http://www.telegraph.co.uk/health/healthnews/9853058/Bulgarian-midwife-almostinjected-new-born-baby-with-lethal-air-bubble.html [Accessed: February 6, 2013].

UKBA (UK Border Agency), 2011. Guidance for Nationals of Bulgaria and Romania on Obtaining Permission to Work in the UK. (BR 1 Guidance Notes, version 06/11). Available at: http://www.ukba.homeoffice.gov.uk/sitecontent/applicationforms/bulgariaromania/guid anceforbulgariaromania0408 [Accessed: June 6, 2014].

Urry, J., 2000. Sociology beyond Societies: Mobilities for the Twenty- First Century. London: Routledge.

ELENA GENOVA is a Sociology PhD Candidate at the University of Nottingham. She is also the co-convenor of the Postgraduate Migration Network.

ADDRESS: School of Sociology and Social Policy, University of Nottingham, University Park, Law and Social Sciences Building, Nottingham, NG7 2RD. Email: lqxesgen@nottingham.ac.uk 
${ }^{1}$ The second data set is part of my ongoing doctoral study on Bulgarian highly skilled migration in the UK that includes both young professionals and students. Hence, the age criterion served to delineate people aged between 18 and 35 (see Rolfe, Fic, Lalani, Roman, Prohaska and Dudeva 2013), whereas location serves to account for regional differences in the attitude towards migrants. Educational level and gender aim to offer a diverse set of responses in relation to young Bulgarian migrants' experiences. For the purposes of this article only student data was utilised. 